\title{
Ways of Seeing Africa
}

\author{
Susan Williams ${ }^{\star 1}$
}

'In the West', claims Molefi Kete Asante in his recent History of Africa, 'the ignorance of Africa is palpable, like a monster that invades our brains with disbelief, deception, and disinterest, yet is everywhere around us. We are victims of probably the most uninformed educated people in the world on the subject of Africa'. It is hard to disagree, given many Western assumptions about the nature of life in any African country. So prevalent are these ideas that Binyavanga Wainaina, a Kenyan writer, offers in his essay 'How to Write about Africa', which struck such a chord with its readers it has since achieved iconic status, some sardonic tips to authors aspiring to write about the continent. 'Always', he advises,

use the word 'Africa' or 'Darkness' or 'Safari' in your title. Subtitles may include the words 'Zanzibar', 'Masai', 'Zulu', 'Zambezi', 'Congo', 'Nile', 'Big', 'Sky', 'Shadow', 'Drum', 'Sun' or 'Bygone'. Also useful are words such as 'Guerrillas', 'Timeless', 'Primordial' and 'Tribal'."

Such representations of Africa inform the background against which the annual Africa Bibliography is published. It seems appropriate, therefore, to look at them more closely. The Bibliography's range and inclusiveness, which embody a significant and compelling literature by Africans and non-Africans alike, reveal a nuanced, rich picture. But this picture is not consistent, by and large, with the perception of the continent from beyond its shores.

The most common cliché about Africa is failure. In the very first sentence of Dark Star Safari (2002), Paul Theroux delivers his grim verdict on the state of the continent: 'All news out of Africa is bad. ${ }^{4} \mathrm{He}$ then proceeds to illustrate this verdict with a bleak account of his overland journey from Cairo to Cape Town. This dismissive view infuriated Barack Obama as he travelled aged twenty-six to Kenya, the land of his father, for the first time. On the flight from London to Nairobi, he records in his memoir, Dreams from My Father, he read a portrait of several African countries by a Western journalist who was 'an old Africa hand'. The first chapters of the book gave an account of colonialism and the early heroism of independence figures like Kenyatta and Nkrumah, followed by a drift towards despotism that was attributed to the politics of the Cold War. But by the third chapter,

images from the present had begun to outstrip the past. Famine, disease, the coups and counter-coups led by illiterate young men wielding AK-47s like

\footnotetext{
* Susan Williams is a Senior Fellow at the Institute of Commonwealth Studies, School of Advanced Study, University of London. Her recent books include Colour Bar. The Triumph of Seretse Khama and His Nation (Penguin 2006) and (co-edited) The Iconography of Independence: 'Freedoms at Midnight' (Routledge 2009). She is currently writing on the decolonisation of central and southern Africa in the context of the global power shifts of the twentieth century.
} 
shepherd sticks - if Africa had a history, the writer seemed to say, the scale of current suffering had rendered such history meaningless.

Poor buggers. Godforsaken countries.

'I set the book down', records Obama, 'feeling a familiar anger flush through me, an anger all the more maddening for its lack of a clear target'.

This picture of Africa as 'Godforsaken countries' is myopic at best. For its history, as Molefi Kete Asante has shown, is 'a major part of the history of the world, since Africa's contributions to humanity are fundamental and expansive'. ${ }^{6}$ Moreover, many African countries have produced one of the most remarkable achievements of the twentieth century - namely, the triumph of majority rule over the moral wrong of colonization and white, racist minority rule. One characteristic of this struggle was the determination of emergent African leaders - many of whom had spent long years in prison to create non-racial societies and to call on their citizens to forgive the white settlers and colonizers.

Until now, Nelson Mandela has been widely regarded in the West as unique in Africa for his values of reconciliation and forgiveness. But, argues Graça Simbine Machel, who was the first Secretary of State for Education in newlyindependent Mozambique and is the widow of President Samora Machel, the South African spirit of forgiveness is widespread and part of a pattern through the continent. 'It is there in our culture', she said in an interview following her marriage to Nelson Mandela. 'When we are faced with such a challenge we draw from that culture which is very deep inside ourselves. ${ }^{7}$

Quett Ketumile Masire, formerly the second President of Botswana, makes a similar point about African culture in Very Brave or Very Foolish? Memoirs of an African Democrat. He questions the West's belief that its own way of doing things is best. 'People are often puzzled', he observes, 'by why some African presidents are so reluctant to make critical public statements about other presidents who are misbehaving'. But, he explains, 'The African approach is to try to be diplomatic, while a European or American approach is to attack problems head-on and often publicly. We believe if you want to influence someone, you have to first make the person understand you are a friend'. 8

No one will deny that the nations of Africa are faced with serious difficulties and challenges, to differing degrees. But this hardly justified Prime Minister Tony Blair's wholesale description of the continent in 2001 as a 'scar on the conscience of the world" - a description that is frequently endorsed by some aid agencies' grainy photographs of starving children. It is as though Africa were one small country, inhabited by victims. But as Richard Dowden, the director of the Royal African Society, points out in Africa.

Altered States, Ordinary Miracles, it is a continent that is vast and diverse, with more than 2000 languages and cultures. In comparison with Africa, 'Europe is homogenous, America monotonous. Who would dare make generalizations about Asia based on Bangladesh? Or about Europe based on Greece? ${ }^{10}$ The late Polish journalist and writer Ryszard Kapuscinski, who first went to Africa in 1957 and then returned again and again over the next forty years, makes a similar point. 'Africa is too large to describe', he observes in his preface to The Shadow of the Sun. 'It is a veritable ocean, a separate planet, a varied, immensely rich cosmos. Only with the greatest simplification, for the sake of 
convenience, can we say "Africa". In reality, except as a geographical appellation, Africa does not exist." 11

Samson Kambalu, a Malawian author and artist, is playful with the image of the African child as victim. In his memoir, The five Talker. Or, How to Get a British Passport, he is frank about the poverty of his youth, after his father lost his government job. He and his siblings were so hungry, he records, that they ate dog food to survive. But they are human beings, not objects of pity. 'Don't let the tourist take your picture', warns Kambalu's father - or 'next thing you know, you are in an Oxfam appeal'. The young Kambalu therefore resists when a British tourist orders him to remove his shoes for a photograph of 'urchins'. In any case, he is proud of his new shoes, which his father had bought him as a reward for being top of the class. He ends up giving in to her, but on his own terms:

I took off my shoes, kicked them away and joined the ragged group. She gave me the thumbs up as I posed with my hands on my hips. I was trying to get one over on her, figuring that she couldn't use that picture for an Oxfam appeal because a hungry person wouldn't look so full of himself. ${ }^{12}$

The Nigerian writer Chinua Achebe has brilliantly tackled the issue of Western attitudes in an article entitled 'Africa's Tarnished Name', first published in 1998 and re-published in 2010 in The Education of a BritishProtected Child. The arsenal of derogatory images of Africa amassed to defend the slave trade and, later, colonization, he argues, gave the world a way of looking at Africa and Africans that still endures. This way of looking was given teeth by the genius of Joseph Conrad's Heart of Darkness (1902), a novel that Achebe dislikes intensely. Halfway through his story, writes Achebe, 'Conrad describes a journey up the River Congo in the 1890s as though it were the very first encounter between conscious humanity, coming from Europe, and an unconscious, primeval hegemony that had apparently gone nowhere and seen nobody since the world was created'.

Naturally, comments Achebe, it is the conscious party that tells the story. He quotes from the novel:

We were wanderers on a prehistoric earth, on the earth that wore the aspect of an unknown planet. We could have fancied ourselves the first of men taking possession of an accursed inheritance.

\section{This passage}

goes on at length through 'a burst of yells,' 'a whirl of black limbs,' 'of hands clapping,' 'feet stamping,' 'bodies swaying,' 'eyes rolling,' 'black incomprehensible frenzy,' 'the prehistoric man himself,' 'the night of first ages.' And then Conrad delivers his famous coup de grâce. Were these creatures really human?

He answers the question, observes Achebe, with the 'most sophisticated ambivalence of double negatives': 'No, they were not inhuman. Well, you know that was the worst of it - this suspicion of their not being inhuman.'13

These 'Congolese clichés', so aptly labelled by Fred Robarts, a human security consultant and writer living in the Democratic Republic of the Congo in 2006-8, are the backdrop to Tim Butcher's popular Blood River: A fourney to Africa's Broken Heart, which follows the route of 
Henry Morton Stanley's expedition through the Congo in the 1870s. Its theme can be summarized as fear, as foreshadowed in the opening paragraph: 'Outside was the Congo and I was terrified. ${ }^{, 14}$ But this representation of the DRC is challenged by Robarts. 'Kinshasa may lack cinemas, bookshops and decent cafes', he acknowledges, but then points out that it 'generally suffers less gun and street crime than London'. ${ }^{15}$

In any case, the ongoing 'heart-of-darkness' mythology is at odds with the emergence of evidence documenting the machinations of the Western powers in post-colonial Congo. Within days of the Congo's independence from Belgium in 1960, the government of the democratically-elected Prime Minister Patrice Lumumba was under threat from the outgoing colonial power. Within ten weeks, records Larry Devlin, who was CIA Station Chief, he had been deposed in a coup engineered by the CIA - the very first coup to take place in post-colonial Africa. Devlin was then given instructions to kill Lumumba. ${ }^{16}$ Within eight months, Lumumba had been murdered by Congolese and Belgian officers, as Ludo de Witte conclusively shows in The Assassination of Lumumba, on the basis of Belgian government records. ${ }^{17}$ As a result of this book, the Belgian government carried out an official investigation into Lumumba's murder and then offered an apology to Lumumba's family and to the Congo for their role in his execution.

This tragedy has been explored in fiction. In the bestselling Poisonwood Bible, the American novelist Barbara Kingsolver weaves the life of the American Price family in the Congo into the political story of independence. 'Devil One', says a mercenary to Rachel, one of the Price girls, 'was supposed to get his so-called operatives to convince the army men to go against Lumumba. Supposedly this Devil One person was going to get one million dollars from the United States to pay soldiers to do that, go against the very person they all just elected' ${ }^{18}$ Kingsolver is clear: the 'Devil' tag belongs to American foreign policy, not to the Congo.

But Conrad's mythology endures: Fred Robarts noticed in 2008 that the US Embassy in Kinshasa sold T-shirts emblazoned with the words, 'I survived the Heart of Darkness'. ${ }^{19}$ It is a strange view of the world: where Africa and Africans are bad, 'accursed' or fail (except for Nelson Mandela), and the West is well-intentioned and successful.

'Africa is a vast continent, a continent of people', insists Chinua Achebe, 'and not a place of exotica, or a destination for tourists'. ${ }^{20}$ However, this is not the impression given by many travel books about Africa, which have a large and loyal market of readers in the West. Butcher has followed Blood River with Chasing the Devil: The Search for Africa's Fighting Spirit, which follows the 1935 foot trek of Graham Greene across Sierra Leone and Liberia. ${ }^{21}$ Its emotive title conjures up the 'black incomprehensible frenzy' of Conrad's Heart of Darkness - the 'devil' image carefully rejected by Kingsolver in her novel. Another recent travelogue is V.S. Naipaul's The Masque of Africa: Glimpses of African Belief, which examines the role of magic in six African countries. ${ }^{22}$ 'There is ammunition here', observes a review in the Telegraph,

for those who say that Naipaul's famous pessimism, applied to Africa, can cross the line into racism. When a Ghanaian demonstrates 'analytical thought', 
Naipaul immediately attributes this facility to one of the man's remote ancestors, a Danish slave trader. ${ }^{23}$

It is significant that Botswana is not on the itineraries of these writers as they travel through the continent. This absence is glaring - for it is an African nation that is simply too successful to fit this pessimistic model of postcolonial Africa. When Botswana became independent from Britain in 1966, it was listed by the United Nations as one of the world's ten poorest nations and the least developed nation in Africa. One quarter of Botswana's people were dependent on famine relief for their basic food needs. But after independence, it was dramatically transformed. It managed the discovery of diamonds so well that for the first twenty-five years of self-rule, it had the fastest economic growth in the world and services for the people were developed throughout the country, almost from scratch. It has its own problems, including high rates of HIV/AIDS, but it is a multi-party, non-racial democracy with recognized low levels of corruption. ${ }^{24}$

Botswana's success may have been overlooked in travelogues, but it is the backdrop to Alexander McCall Smith's series of stories about Precious Ramotswe, a fictitious woman detective. In these books, starting with The No 1 Ladies' Detective Agency (1998), Mma Ramotswe solves mysteries through common sense and humanity, against a backdrop of ordinary, everyday Botswanan life. McCall Smith, who drew on his experience of living in Botswana to write these books, is conscious that they present a picture of Africa that runs counter to Western attitudes. He expressed his sadness about this in an interview in the USA in 2009:

McCall Smith: It's not just my reaction to the country. People say what a wonderful place. People say that similarly about many sub-Saharan African countries. Without romanticizing the place, people there have great human qualities which really are very very striking. When you see the picture that's presented of Africa, of sub-Saharan Africa, you don't see that. I think this is a terrible pity.

Interviewer: They have diamonds. They have the Kalahari. They suffer from the AIDS epidemic. That's pretty much the summary you read in the press.

McCall Smith: There's that side of it, too, in sub-Saharan Africa. But there are human qualities which are wonderful. Very interesting cultures with a lot to say. Yet all we get is a picture of disasters. ${ }^{25}$

\section{Potential of new media}

Perhaps the internet will start to challenge this 'picture of disasters', since it offers almost limitless opportunities for representing, and seeing, Africa. Jos Damen at the Africa Studies Centre Library in Leiden reported in 2008 that approximately 2,000 e-journals were published in Africa that year and that about 2,500 e-journals contained articles about Africa. ${ }^{26}$ The Africa Bibliography, too, will be available online from January 2011.

But there is a major obstacle - the inequity of global access to the new media. According to Sayan Chakraborty (2008), only one in 700 people in Africa had access to the internet at that date, as compared to one in four people in Europe. Lack of electricity and frequent blackouts compound the problem. In Kenya, for example, only 12 per cent of the population had 
electricity. 'But above all', writes Chakraborty, 'only a tiny minority can afford to buy a computer. Internet access is available at cybercafés in cities but the costs are still prohibitive. The average monthly cost of 20 hours of internet access is higher than the average monthly wage'. ${ }^{27}$ Between 2000 and the end of 2008, the number of internet users in Africa rose from 3,000,000 to $32,000,000$. But even so, fewer than five per cent of Africans in 2009 used the internet, and fixed and mobile broadband penetration levels were negligible. $^{28}$

This has led to a situation where, at least on some websites, the view of Africa by people outside the continent seems to predominate over the multiple views of Africans themselves. In her article, 'Africa on YouTube', Melissa Wall shows that when videos about Kenya and Ghana are posted on YouTube, they mostly come from the West. The two major categories of videos are musical and tourist: and in the case of the latter, they are generally scenes of wildlife in which Westerners give a meaning that is based not on understanding the local scene, 'but upon their own, generally very different western frameworks'. In the case of the tourism videos, the posters often put themselves in the very centre. This is a real worry, argues Wall, since Africa is 'one of the most misrepresented regions of the world'. ${ }^{29}$

The picture is not as pessimistic, however, as it at first appears. Senegal, which leads Africa in international connectivity, thanks in part to its coastal location, added a million people to its number of internet users between 2000 and 2008. One in twelve inhabitants now has a home computer, and a similar proportion uses the internet. ${ }^{30}$ Moreover, as James A Coleman and Tony Chafer observe in their article on 'Study Abroad and the Internet', 'It is a truism that the world is not the same since the advent of the Internet. Has the sense of distance evolved over recent decades? Undoubtedly'. 'Abroad', they conclude, 'is less abroad than it once was'. ${ }^{31}$

Significantly, the Nelson Mandela Centre of Memory, which was launched in Johannesburg in September 2004 to document Mandela's life and promote his legacy, has turned to the internet to bring South African history out of the archives and into South African and global communities. Because materials documenting Mandela's life and work are fragmentary and scattered, both geographically and institutionally, the Centre brings them together on a single web-based portal in order to take the archive out to the people of South Africa and beyond, not restricting it to academics and to people who are able to visit the institution. This effort is the result of a conscious political commitment, as part of a continuing walk to freedom.

People in Africa have already used the mobile phone to transform great parts of life across the continent. In Less Walk, More Talk (2008), Russell Southwood traces the transformation of the continent by the mobile phone. The West, he explains, largely refused to invest in the mobile phone in Africa on the grounds that - 'this being Africa' - it was bound to fail. But the industry has been built and developed by African business and has been a huge success. One African company, Celtel, went from a handful of people with virtually no money, to a multibillion dollar company in just seven years. This has had an astonishing effect, bringing easy communication to places with no roads, no landlines, even to places devastated by war. Mobile growth, enthuses Southwood, has been 'the electric force that has energized the emergence of a new kind of Africa'. ${ }^{32}$ 
Yet another 'electric force' affecting attitudes to Africa took place thousands of miles away from its shores - the election of Barack Obama in 2008. The following year, the Ghanaian journalist Cameron Duodu discussed the impact of Obama's presidency in the magazine New African. As a boy in the British-ruled Gold Coast everything was decided by what Duodu calls the 'unseen "white men"'. But, bit by bit, he writes, everything changed: in 1957 Ghana became the first African country to become independent and it was swiftly followed by other African countries - even apartheid South Africa achieved majority rule in the last decade of the twentieth century. 'Was I dreaming or seeing reality? South Africa?' he asks. 'I mean I just couldn't believe my own eyes.' His dream of a non-racial Africa had miraculously come true. Little did he envisage then the election of Barack Obama as American President. In an article evocatively titled 'Our Son', 'A black man, fathered by a Kenyan', marvels Duodu, 'was president of the USA! 33

A sea change in Western attitudes to Africa is surely overdue. 'For too long', writes Chinua Achebe, 'the world has been content to judge peoples and nations in distress largely on the basis of received stereotypes drawn from mythologies of oppression'. ${ }^{34}$ Scholars have a role to play in this muchneeded shift in perception, by contributing to new knowledge about Africa asking fresh questions, evaluating evidence and exploring ways of thinking about the continent and its peoples. Many of these scholars belong to a community that is determined to go beyond the tired, insulting and illinformed clichés of a so-called 'heart of darkness'. Their hard work and patient research, conducted across Africa and other parts of the world, fill the many pages of this Africa Bibliography.

\footnotetext{
${ }^{1}$ The author is grateful for helpful contributions by Tendayi Bloom, Gervase Hood, Stephanie Kitchen and Peter Sebina.

${ }^{2}$ Molefi Kete Asante (2007) The History of Africa. The quest for eternal harmony, London: Routledge, p. xiii.

${ }^{3}$ Binyavanga Wainaina (2005) 'How to Write About Africa', The View from Africa, Granta 92, p. 92, Winter.

4 Paul Theroux (2002) Dark Star Safari, London: Hamish Hamilton, p. 1.

${ }^{5}$ Barack Obama (1995) Dreams From My Father. A story of race and inheritance, Edinburgh: Canongate, p. 300.

${ }^{6}$ Molefi Kete Asante, The History of Africa, p. xiii.

${ }^{7}$ From an interview with Graça Machel by Anthony Sampson, 22 February 1998, quoted in Anthony Sampson (1999) Mandela. The authorised biography, London: HarperCollins, p. 533.

${ }^{8}$ Quett Ketumile Joni Masire (2006) Very Brave or Very Foolish?, ed. Stephen R Lewis, Gaborone: Macmillan, p. 296.

9 Tony Blair, 2 October 2001, quoted in the Independent, 21 August 2004.

${ }^{10}$ Richard Dowden (2008) Africa. Altered States, Ordinary Miracles, London: Portobello, pp. 9-10.

11 Ryszard Kapuscinski (2001) The Shadow of the Sun. My African life, London: Penguin, preface (not paginated).

12 Samson Kambalu (2008) The Five Talker. Or, how to get a British passport. London: Jonathan Cape, pp. 70, 94-5.

${ }^{13}$ Chinua Achebe (1998) 'Africa's Tarnished Name' in (2010) The Education of a British-Protected Child, London: Penguin, pp. 81-2.

14 Tim Butcher (2007) Blood River, London: Vintage, p. xi.

${ }^{15}$ Fred Robarts (2008), 'Congolese Clichés', Frontline Club, <http://frontlineclub.com/news/ 2008/04/congolese-cliches.html>, 20 April.

${ }^{16}$ Larry Devlin, who was CIA Station Chief in the Congo at that time, records the CIA's instrumental role in the coup in (2007) Chief of Station, Congo, New York: Public Affairs, chs 6-7.
} 
17 Ludo De Vitte (2001) The Assassination of Lumumba, trans by Ann Wright and Renée Fenby, London: Verso; first published as De Moord op Lumumba, 1999.

${ }^{18}$ Barbara Kingsolver (1998) The Poisonwood Bible, London, Faber and Faber, p. 334.

19 Fred Robarts (2008) 'Congolese Clichés', op. cit.

${ }^{20}$ Chinua Achebe (2008) 'Foreword', in Dowden, Africa, Altered States, Ordinary Miracles, p. xv.

21 Tim Butcher (2010) Chasing the Devil. London: Chatto \& Windus.

22 V S Naipaul (2010) The Masque of Africa: London: Picador.

${ }^{23}$ Ed O'Loughlin (2010) review of The Masque of Africa, in the Sunday Telegraph, 5 September.

${ }^{24}$ Susan Williams (2006) Colour Bar. The triumph of Seretse Khama and his nation, London:

Penguin, pp. 317-30.

${ }^{25}$ Vickie Karp (2009) 'Third Screen. A big HBO series about a woman named Precious', Huffington Post, 25 March.

${ }_{26}$ Jos Damen (2008) 'Electronics Journals and Africa: an overview and trends', paper given to the CODESRIA Conférence sur la publication et la diffusion électronique, Dakar, 6-7 October 2008, $<$ http://www.codesria.org/IMG/pdf/01_Jos_Damen-2.pdf>

${ }^{27}$ Chakraborty, S. (2008) 'Mobile Phones Bridging the Information Divide. Issues and lessons from Africa', JOMC 233: Global Impact of New Communication Technologies, University of North Carolina at Chapel Hill, <http://www.unc.edu/ sayanc/globalcomm/Africa-mobile_phones.pdf>

${ }^{28}$ International Telecommunications Union (2009) Information Society Statistical Profiles 2009 Africa, <http://www.itu.int/ITU-D/ict/material/ISSP09-AFR_final-en.pdf>

${ }^{29}$ Melissa Wall (2009) 'Africa on YouTube: musicians, tourists, missionaries and aid workers', International Communication Gazette 71, pp. 333-407.

${ }^{30}$ International Telecommunications Union (2009) Information Society Statistical Profiles 2009 Africa, <http://www.itu.int/ITU-D/ict/material/ISSP09-AFR_final-en.pdf>

${ }^{31}$ James Coleman and Tony Chafer (2010) 'Study abroad and the internet: physical and virtual context in an era of expanding telecommunications', Frontiers, p. 13, Fall.

${ }^{32}$ Russell Southwood (2008) Less Walk, More Talk. How Celtel and the mobile phone changed Africa, Chichester: John Wiley, p. xvii.

33 Cameron Duodu (2009) 'Our son', New African, pp. 14-17, February.

${ }^{34}$ Chinua Achebe $(1998,2010)$ 'Africa is People', in The Education of a British-Protected Child, p. 166. 